https://doi.org/10.22364/lviz.114.09

\title{
PRETOŠANĀS, KOLABORĀCIJA UN HOLOKAUSTS: ZINĀTNISKIE LASĪJUMI "LIMBAŽI PADOMJU UN NACISTU OKUPĀCIJAS VARU KRUSTPUNKTĀ (1941): CERĪBAS UN VILŠANĀS”
}

2021. gada 3. jūlijā Limbažu muzeja teritorijā notika Latvijas Universitātes Latvijas vēstures institūta (LU LVI) zinātniskie lasījumi "Limbaži padomju un nacistu okupācijas varu krustpunktā (1941): cerības un vilšanās”, kas bija veltīti 1941. gada 4. jūlija Limbažu kaujas 80. gadadienai un holokaustā nogalināto Limbažu ebreju piemiņai. Lasījumos vēsturnieki un sociālās atmiṇas pētnieki uzstājās ar referātiem un piedalījās diskusijās par Vācijas-PSRS kara sākumu, bezvaras periodu un okupācijas varu maiṇu 1941. gada jūnijā-jūlijā; nacionālajiem partizāniem un Limbažu kauju; pašaizsardzības komandantūrām un to iesaisti holokaustā; kā arī par 1941. gada vasaras notikumu pieminēšanu un nospiedumiem sabiedrības sociālajā atmiṇā.

Zinātniskie lasījumi norisinājās Latvijas Zinātnes padomes (LZP) projekta "Pārvērtējot bezvalstiskumu: Pretošanās un kolaborācija Latvijā Otrā pasaules kara laikā” (lzp-2020/2-0212) ietvaros, kas no 2020. gada 1. decembra līdz 2021. gada 31. decembrim tiek īstenots LU LVI. Vēsturnieki un sociologi pievērsās problemātikai, kas līdz šim akadēmiski pētīta vai publiski izskanējusi lielākoties tikai kā atsevišķa un viena no otras atrauta tematika. Atškşirībā no Igaunijas Kara muzeja - Ģenerāḷa Laidonera muzeja un Baltijas Aizsardzības koledžas organizētās starptautiskās zinātniskās konferences (2021. gada 21.-22. septembrī Tartu), kas fokusējās tikai uz militārās vēstures jautājumiem, Limbažos aizvadītie lasījumi iezīmējās ar plašāku skatījumu, ietverot tajā arī holokausta un mūsdienu vēstures un atmiņas procesu un politikas analīzi. Lìdz ar to šis bija mēǵinājums detalizēti un konceptuāli izvērtēt 1941. gada vasarā notikušo pretošanos un sadarbību ar padomju un nacistu okupācijas režīmiem, vienlaikus cenšoties izprast šo pagātnes norišu un tām veltīto piemiņas vietu "sadzīvošanu” mūsdienu kolektīvajā atmiṇā, neizvairoties arī no sāpīgām un pretrunīgi vērtētām pagātnes tēmām.

Lasījumu pirmā daḷa aptvēra militāri politiskos notikumus VācijasPSRS kara pirmajās dienās un nedēḷās, kas Ziemeḷlatvijā radīja bezvaras stāvokli un labvēlīgus apstākḷus nacionālo partizānu grupu darbībai, 
tostarp Limbažu kaujas norisei. Latvijas Nacionālās aizsardzības akadēmijas pētnieks Valdis Kuzmins analizēja vācu un padomju karaspēka daḷu pieņemtos lēmumus, kas bija izšķiroši un ietekmēja gan abu pušu sekmes Latvijas teritorijā un Baltijā kopumā, gan atstāja lielu ietekmi uz bezvaras perioda izpausmēm dažādās Ziemeḷlatvijas vietās. Izmantojot tikai pēdējos gados atslepenotus dokumentus, V. Kuzmins pārliecinoši demonstrēja, ka šīs ìpatnējās situācijas cēlonis bija ne vien Vācijas armijas vienību sekmīgie uzbrukumi pie Daugavpils, Jēkabpils, Rīgas u. c., bet arī konkrētās PSRS Ziemeḷrietumu frontes vadības direktīvas, kas pārtrauca mēginājumus atgūt zaudētās pozīcijas Latvijā, atkāpjoties dziḷāk Igaunijas teritorijā. Šis lēmums apturēja vācu plānus par drīzu L̦eņingradas ieņemšanu un piespieda tos iesaistīties smagās kaujās Igaunijā.

Limbažu muzeja vēsturnieks Juris Pavlovičs apskatīja bezvaras perioda izveidošanos no padomju varas pieņemto lēmumu un vietējo iedzīvotāju tā brīža skatpunkta. Skrupulozi izsekojot notikumu virzībai Valmieras apriņ̧̧̦ī, viņš norādīja, ka līdz pat 1941. gada 4. jūlijam šeit joprojām strādāja veikali, bankas un citas iestādes, kaut daḷeji bija sākusies padomju iestāžu evakuācija. 2. jūlijā apriṇ̣̂ī izsludināja karastāvokli, bet par bezvaras perioda sākuma laiku var uzskatīt 4 . jūlija agru pēcpusdienu (plkst. 13:00), kad padomju 8. armija izdeva pavēli visām palikušajām padomju varas aizstāvju vienībām evakuēties. Limbažu kauja šìs pavēles izpildi aizkavēja, bet pēc kaujas, uzzinot par šo pavēli, padomju aktīvisti un jūrnieki līdzīgi kā citi - metās bēgt. J. Pavlovičs uzsvēra, ka hronologiski tik îsa perioda pētniecībā vairumu atmiṇu un citu memuārliteratūru liedz izmantot cilvēka atmiņas specifika, kas nẹ̦auj precīzi atminēties notikušā detaḷas. Jāpiebilst gan, ka bezvaras perioda pētniecībā avotu klāsts ne vienmēr ir pietiekams, tādēl būtu jāizmanto visi pieejamie avoti, t. sk. pēckara Latvijas PSR VDK krimināllietu materiāli, tos kritiski izvērtējot. It īpaši tas ir svarīgi, cenšoties rekonstruēt ne tikai padomju režīma sabrukuma pēdējo dienu realitāti, bet arī bezvaras norišu un jauno varas institūciju izveides mehānismu.

Viens no sekojošās diskusijas jautājumiem bija par to, kā no starptautisko konvenciju viedokḷa būtu vērtējami nacionālie partizāni, kuri konvencionāla kara ietvaros divu okupācijas varu žņaugos cīnījās par savas valsts suverenitātes atgūšanu. V. Kuzmins uzsvēra, ka vizuālajos materiālos pamanāms, ka sarkanbaltsarkanie piedurknes apsēji, ko nēsāja latviešu partizānu un pašaizsardzības vienības, bija mēǵinājums sevi legitimēt vācu varas acīs. Arī okupētas valsts iedzīvotāju cīṇa par valstisko neatkarību ir cieņas vērta un būtu atzīstama arī no starptautisko kara konvenciju viedokḷa. 
LU LVI zinātnisko lasījumu "Limbaži padomju un nacistu okupācijas varu krustpunktā (1941): cerības un vilšanās" plakāts

Poster of the ILH UL scholarly readings "Limbaži at the Point of Intersection of Soviet and Nazi Occupation Rules (1941): Hope and Disappointment"
Latvijas Universitātes Latvijas vēstures institūta zinātniskie lasījumi sadarbībā ar Limbažu muzeju un Limbažu Galveno bibliotēku

\section{Limbaži}

padomju un nacistu okupācijas varu krustpunktā (1941): cerības un vilšanās

Veltiti 1941. gada 4. jūlija Limbažu kaujas 80-gade un holokaustā nogalināto Limbažu ebreju pieminai

Limbažu muzeja teritorijā (Burtnieku ielā 7), 2021. gada 3. jūlijā plkst. 11.00-17.00

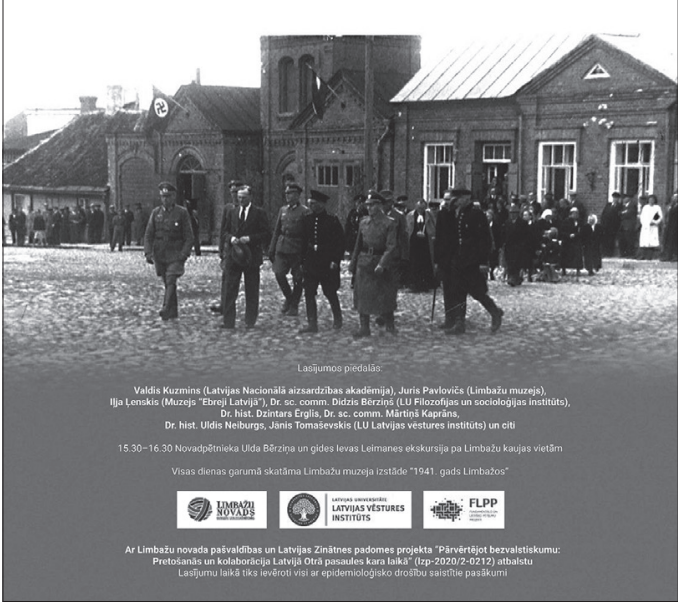

Lasījumu otrā daļa bija cieši saistīta ar 1941. gada jūlija notikumiem Limbažos, kur varēja vērot gan pretošanās, gan kolaborācijas/kolaboracionisma izpausmes un pat to sadursmi. LZP projekta pētnieks un LU Vēstures un filozofijas fakultātes doktorants Jānis Tomaševskis analizēja Limbažu kaujā iesaistīto pušu sastāvu, mēginot iezīmēt tās dalībnieku kolektīvo portretu un tā korelāciju/disonansi ar situāciju Latvijā kopumā. Ieviešot zinātniskajā apritē līdz šim maz izmantotus vēstures avotus - Latvijas Statistikas pārvaldes 1942. gada anketēšanas rezultātus, vēsturnieks secināja, ka Limbažu atbrīvotāju - nacionālo partizānu rindās bija būtiski lielāks profesionālo militārpersonu īpatsvars nekā vairumā citu partizānu vienību. Tā iemesls bija gan liels Sarkanās armijas 24. teritoriālā korpusa dezertieru īpatsvars, gan citas šìs nacionālo partizānu grupas veidošanās īpatnības. L,oti iespējams, ka Limbažu atbrīvotāji nemaz nejutās kā partizāni, bet gan teju kā regulāra armijas dạ̦a, kas veica frontālu iebrukumu pilsētā. Arī bruṇojums šiem karavīriem bija krietni augstvērtīgāks nekā vairumam partizānu vienību, 
kuras tamdēḷ bija spiestas savas aktivitātes ierobežot, kas kopumā negatīvi atsaucās uz viṇu darbības rezultātiem. Limbažos un dažās citās vietās situācija bija salīdzinoši labāka, tādējādi arī bija pamats cerībām gūt lielākus panākumus.

Analizējot padomju puses sastāvu, J. Tomaševskis pamatoti norādīja, ka Limbažu kaujā iesaistīto padomju formējumu dalībnieku maksimālais skaits varēja sasniegt 200 (nevis 1000, kā minēts atsevišķos avotos) cilvēku, no kuriem apmēram puse varēja būt bijušie Latvijas pilsoṇi. Limbaži bija viena no daudzām vietām Latvijā, kur 1941. gada vasarā bija novērojami t. s. pilsoṇu kara elementi, kad viena pret otru vērsās dažādas vietējo iedzīvotāju grupas. Šādas tendences saglabājās arī pēc Limbažu kaujas, kad vietējās pašaizsardzības komandantūras locekḷi nacistu okupācijas varas uzraudzībā īstenoja represijas pret pilsētas ebrejiem.

Balstoties uz līdzšinējām mikrovēstures pētniecības atziṇām, LU LVI pētnieks Dzintars Ērglis holokausta norisi Limbažos analizēja plašākā Latvijas provinces ebreju iznīcināšanas kontekstā. Līdzīgi kā citās mazpilsētās, arī Limbažu ebreju kopienai bija niecīgas izredzes izglābties, un gandrīz visi pilsētas ebreji (izṇemot tos, kuri aizbēga līdzi padomju spēkiem) tika iznīcināti līdz 1941. gada rudenim. Kopumā pilsētā un tās apkārtnē noslepkavoja vairāk nekā 70 ebreju vismaz 16 slepkavošanas vietās. Šo vietu daudzums bija neraksturīgs situācijai Latvijā kopumā - mazpilsētās bieži ebrejus nogalināja vienā dienā vienā konkrētā vietā.

Diskusijas turpinājās, cenšoties noskaidrot gan nacionālo partizānu, gan pašaizsardzības komandantūras locekḷu rīcības motivāciju. J. Tomaševskis to vērtēja kā sarežgìitu izpētes objektu, kam grūti sniegt viennozīmīgu vērtējumu. Limbažu atbrīvotāju - partizānu - gadījumā noprotams, ka viṇu primārais mērḳis bija aizdzīt padomju varu no konkrētās apdzīvotās vietas. Šāda motivācija noteikti bija visiem - pat tiem, kuri varēja saņemt pilnvaru no Rīgas latviešu komandanta pulkveža-leitnanta Voldemāra Veisa vai kādas citas latviešu amatpersonas. Tālākais (ilgtermiṇa) mērķis bija Latvijas neatkarības atjaunošana, ko par savu motivāciju sauca daudzi no tiem, kas pēc kara nonāca padomju drošỉbas iestāžu apcietinājumā. Par vācu varas ilgtermiņa mērķiem tie latviešu virsnieki, kuri darbojās pašaizsardzības spēku štābā Rīgā, iespējams, varēja sākt nojaust tikai 1941. gada jūlija vidū (viens no spēcīgākajiem signāliem varēja būt pulkveža-leitnanta Viktora Deglava mīklainā nāve 18. jūlijā), bet ne agrāk.

Pievēršoties Limbažu pašaizsardzības komandantūras locekḷ darbības motivācijai, Dz. Ērglis pamatoti norādīja, ka nacistu okupācijas vara spēja latviešu patriotismu izmantot savu mērķu īstenošanai. Lielajās pilsētās ebrejiem bija kaut nelielas iespējas izdzīvot, bet mazpilsētās, tostarp 


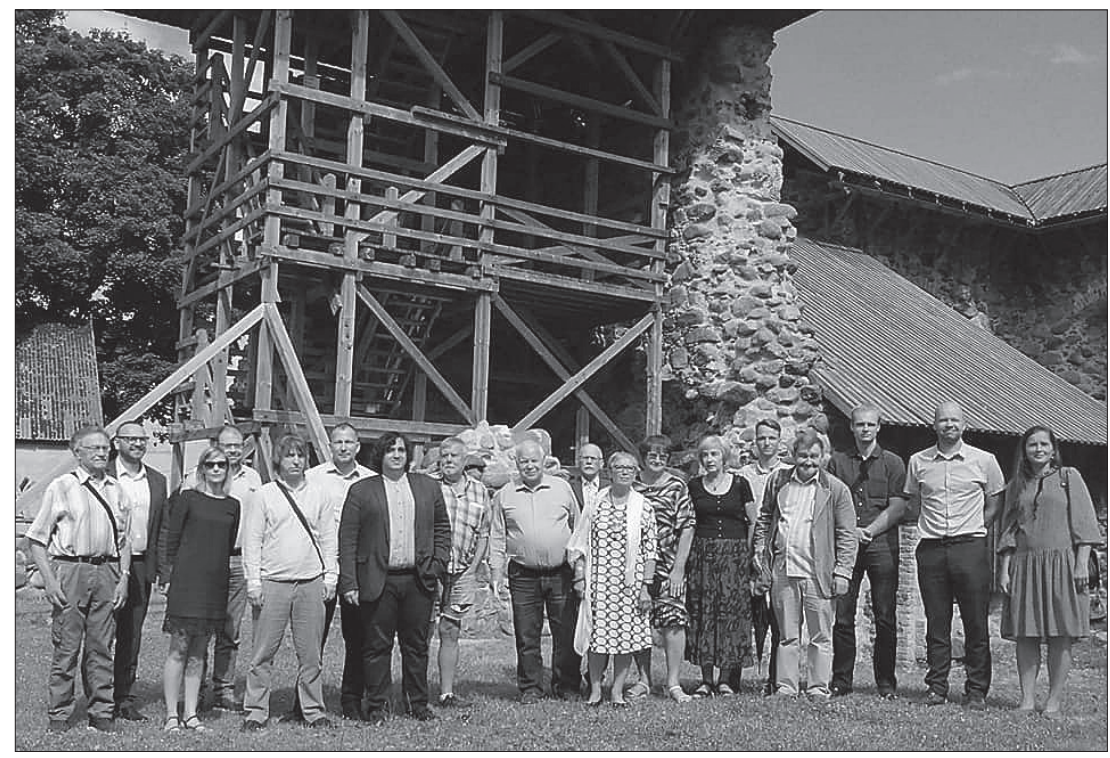

LU LVI zinātnisko lasījumu "Limbaži padomju un nacistu okupācijas varu krustpunktā (1941): cerības un vilšanās” dalībnieki pie Limbažu pilsdrupām. 2021. gada 3. jūlijs

Participants of the ILH UL scholarly readings "Limbaži at the Point of Intersection of Soviet and Nazi Occupation Rules (1941): Hope and Disappointment" at Limbaži Castle ruins, 3 July 2021

Limbažos, holokausts bija tik totāls, ka šeit gāja bojā faktiski visi ebreji. Izglābties varēja tikai tie, kurus kāds uzņēmās glābt. Turpmākā pētniecībā būtu jāskaidro dažādi motivācijas aspekti, piemēram, cik liela daḷa nacionālo partizānu iesaistījās kaujās tādēḷ, ka padomju vara bija represējusi viṇu tuviniekus, kā arī tas, cik liela daḷa no partizāniem kḷuva par pašaizsardzības locekḷiem, bet cik liela dạ̦a atteicās darboties vācu okupācijas varas pakḷautībā. Tāpat būtu vērts pētìt, kā piederība kādai konkrētai varas struktūrai varēja ietekmēt kā partizānu un pašaizsardzībnieku, tā padomju aktīvistu rīcības motivāciju.

Lasījumu noslēdzošā sekcija bija veltīta 1941. gada notikumu atcerēšanās/aizmiršanas procesiem Latvijas iedzīvotāju atmiņā un to reprezentācijai mūsdienās. LU Filozofijas un sociologijas institūta (FSI) un LZP projekta "Sarežg̀îtais vēsturiskais mantojums Latvijā: holokausta tūrisma vietas starp piemiņas kultūru, mūsdienu tūrisma pieprasījumu un piedāvājumu" (lzp-2019/1-0241) vadošais pētnieks Didzis Bērziṇš, runājot par holokausta sociālo atmiṇu Limbažos, Vidzemes regionā un valstī 
kopumā, uzsvēra, ka Latvijā ir apzinātas vairāk nekā 250 holokausta piemiņas vietas, no kurām 16 atrodas Limbažu apkārtnē. Limbaži izceḷas ne tikai ar piemiņas vietu prāvo skaitu, bet arī ar šo notikumu izpēti, kurā lieli nopelni ir vietējam novadpētniekam Uldim Bērziņam, kurš šogad laidis klajā grāmatu "Laikmets, kad bija jāraud pat akmeņiem". Tomēr, neskatoties uz atsevišķiem pūliņiem un šīs tēmas starptautisko nozīmību, Latvijā joprojām ir veicams liels darbs, lai holokausta atmiṇu iedzīvinātu plašākos sabiedrības slāṇos.

LZP projekta "Pārvērtējot bezvalstiskumu: Pretošanās un kolaborācija Latvijā Otrā pasaules kara laikā” (lzp-2020/2-0212) un LU FSI vadošais pētnieks Mārtiņš Kaprāns savā ziņojumā aktualizēja virkni problēmjautājumu, kā vērtēt pretošanos un kolaborāciju dubultās agresijas (okupācijas) apstākḷıs; kur šādā situācijā vilkt robežlīniju starp varonību un nodevību; kādi ir nosacījumi, kad varonība/nodevība ir absolūta, bet kad tā ir situatīva un atkarīga no apstākḷiem; ko vērtēt augstāk - bruņoto vai nevardarbīgo pretošanos; kā novērtēt sadarbību ar vienu okupācijas režīimu, lai pretotos otram, u. tml. M. Kaprāns arī uzsvēra, ka, analizējot LZP projekta ietvaros veiktās sociologiskās aptaujas par sabiedrības attieksmi pret kolaborāciju un pretošanos Latvijā Otrā pasaules kara laikā un salīdzinot tās rezultātu dinamiku ar iepriekšējo gadu aptaujām, vērojama aizmiršanas tendence, kas redzama arī kopumā vājajās zināšanās par 1941. gada vasaras notikumiem Latvijā.

Noslēguma diskusijā klātesošie dalījās pārdomās par dažādām komemorācijas tradīcijām un to trūkumu Limbažos un tuvākajā apkārtnē. Attiecībā uz 1941. gada notikumu tālāko izpēti un vietu kolektīvajā atmiṇā D. Bērziņš̌ un muzeja "Ebreji Latvijā" direktors vēsturnieks Iḷja L,enskis bija vienisprātis, ka Limbaži ir labs piemērs, kur ar tūrisma maršruta palīdzību varētu parādìt Latvijas vēstures sarežgìitìbu. Bet vispirms būtu jāpadara saprotama katra atsevišķā notikuma norise un atcere. M. Kaprāns atzina, ka 1941. gada nacionālo partizānu darbības nenovērtēšanai ir gan objektīvi faktori (šo norišu šaurās hronologiskās robežas, pretrunīgums un kontekstu pārklāšanās ar turpmākiem notikumiem), gan subjektīvi faktori, kādēḷ tie kolektīvajā atmiņā nav spējuši kḷūt par "kondensētu simbolu”, par kādu ir kḷuvuši pēckara mežabrāḷi.

Lasījumu noslēgumā I. L̦enskis aicināja kolaborāciju vērtēt caur neatkarīgās Latvijas prizmu, proti, saprast, vai tie cilvēki, kuri kara gados sadarbojās ar padomju vai nacistu okupācijas varu un pastrādāja noziegumus pret saviem līdzpilsoņiem, būtu līdzīgi rìkojušies arī miera laika Latvijā. LU LVI pētnieks Uldis Neiburgs atzina, ka cilvēki dubultās okupācijas apstākḷos bija dezorientēti un ne visi spēja saglabāt augstus 
morālos kritērijus. Par to būtu jādomā, izvirzot nākamos pētniecības uzdevumus un meklējot atbildes uz šo lasījumu laikā aktualizētiem problēmjautājumiem.

LU LVI zinātniskie lasījumi, kas norisinājās ar Limbažu novada pašvaldības atbalstu un sadarbībā ar Limbažu muzeju un bibliotēku, pulcēja plašu interesentu loku un bija labs piemērs sadarbībai vairāku Latvijas pētniecisko un zinātniski izglītojošo institūciju starpā. Nākamais solis varētu būt sadarbībā ar Lietuvas un Igaunijas vēsturniekiem veikta 1941. gada vasaras notikumu salīdzinoša analīze Baltijas regiona vēstures kopīgā kontekstā. Apsveicama būtu arī šīs tematikas iekḷaušanās plašākā Vācijas-PSRS kara sākuma un holokausta izpētes starptautiskā apritē, kliedējot gan vietējā, gan ārzemju akadēmiskajā vidē un publiskajā telpā vēl mūsdienās nereti izplatìtos stereotipus un mītus par šo laiku.

\section{RESISTANCE, COLLABORATION, AND HOLOCAUST: \\ SCHOLARLY READINGS "LIMBAŽI AT THE POINT OF INTERSECTION OF SOVIET AND NAZI OCCUPATION RULES (1941): HOPE AND DISAPPOINTMENT"}

On 3 July 2021, Limbaži Museum hosted scholarly readings of the Institute of Latvian History, University of Latvia (ILH UL), that carried the title "Limbaži at the Point of Intersection of Soviet and Nazi Occupation Rules (1941): Hope and Disappointment" and were dedicated to the $80^{\text {th }}$ anniversary of Limbaži battle and the memory of the Jewish residents of Limbaži killed during the Holocaust. The speakers at the readings were Latvian historians Valdis Kuzmins, Juris Pavlovičs, Jānis Tomaševskis, and Dzintars Ërglis, as well as researchers of social memory Didzis Bērziņš and Mārtiņ̌̌ Kaprāns who delivered presentations and discussed the following topics: the onset of the Germany-USSR war, the interregnum period and change of occupation rules in June-July 1941; national partisans and Limbaži battle; self-defence (Selbstschutz) commandants' offices and their involvement in the Holocaust; as well as the commemoration and imprints of the events of the summer of 1941 on social memory. The readings aimed in a detailed manner and conceptually to evaluate the resistance to and collaboration with the Soviet and Nazi occupation regimes in the summer of 1941, at the same time aspiring to understand the "cohabitation" of these past events and the place of their remembrance in the contemporary collective memory, while not avoiding also painful and controversial historical topics.

The presentations and discussions led to important conclusions, which allowed taking stock of what has been researched and outlining future research tasks. First, military and political developments in the first days and weeks of the Germany-USSR war in the northern part of Latvia, where there 
were practically no hostilities between the warring parties in this period, created benevolent conditions for Limbaži battle and interregnum to take place. Second, the composition of the ranks of the liberators (national partisans) and defenders (Soviet activists) of Limbaži was an essential evidence of the presence of the elements of civil war both in Limbaži and elsewhere in Latvia in the summer of 1941. Such trends persisted after Limbaži battle when, under the supervision by the Nazi occupation authorities, the members of the local self-defence commandant's office carried out repressions against the Jewish residents of the town. Third, in Latvia there have been identified more than 250 Holocaust commemoration sites, of which 16 are located in the vicinity of Limbaži. This town strikes not only with the large number of commemoration sites, but also with the conducted research of the relevant events. However, in spite of individual efforts and the international significance of the topic, much work still needs to be done to make the memory of the Holocaust alive in broad public circles in Latvia. Fourth, the underestimation of the activities of the national partisans in 1941 is due both to objective factors (the narrow chronological framework and controversial character of the respective events as well as the overlapping of the contexts with the subsequent developments) and subjective factors, due to which these combatants have failed to become a "condensed symbol" in the collective memory, such as the post-war pro-independence partisans.

The researchers reached a consensus that the future research should investigate the aspects of the motivation of both the resistance and collaboration, namely, find what proportion of national partisans took part in the battles because the Soviet rule had repressed their relatives, what proportion of partisans joined the ranks of the self-defence, and what proportion of them refused to work under the German occupation rule. It would also be worthwhile to study how belonging to a specific power structure could have affected the motivation of both the partisans and self-defence members and Soviet activists. Historians and scholars of the social sciences should likewise aspire to answer the following questions: how to assess resistance and collaboration in a situation of double aggression (occupation); where one should draw a line between heroism and treason; under what conditions heroism/ treason is absolute and when it is conditioned by the respective situation; which should be valued higher: armed or non-violent resistance; and how to evaluate co-operation with one occupation regime with the aim of resisting the other? It would be valuable to co-operate with Lithuanian and Estonian historians in order to conduct comparative analysis of the events of the summer of 1941 in the context of the history of the Baltic region. It would also be commendable to incorporate the study of the relevant topic in a broader international circulation of the research of the onset of the Germany-USSR war and the Holocaust to disperse the stereotypes and myths about this period that still are infrequently spread both in the local and foreign academic environment and public space. 